\title{
IDENTIFIKASI CEMARAN ESCHERICHIA COLI PADA DAGING AYAM DARI PASAR TRADISIONAL DAN SUPERMARKET DI KOTA TANGERANG TAHUN 2015
}

\author{
*Nining Kurniati, *Shufiyani
}

\begin{abstract}
Abstrak
Perkembangan perekonomian dewasa ini makin meningkat, sehingga permintaan bahan pangan yang bernilai gizi tinggi juga makin meningkat. Daging ayam merupakan salah satu bahan makanan yang cukup popular di masyarakat, juga sebagai sumber protein hewani yang baik dan mempunyai banyak kelebihan. Dirjen Peternakan dan Kesehatan Hewan Kementan Syukur Irwanto mengatakan, konsumsi nasional akan daging ayam tahun 2014 sebesar $8 \mathrm{~kg}$ per kapita per hari. Sementara produksi daging ayam dapat mencukupi hingga $15 \mathrm{~kg}$ per kapita per tahun. Kerusakan karkas selama pemotongan ayam mencapai 10-20\%. Kerusakan terbesar (90\%) disebabkan karena adanya memarmemar yang terjadi 1-13 jam sebelum pemotongan dan 38\% terdapat pada bagian dada dan paha, sehingga bakteri lebih mudah mengkontaminasi daging ayam bagian dada dan paha. Metode yang digunakan dalam penelitian ini adalah Angka Lempeng Total dengan mengambil 4 sampel ayam di 2 lokasi supermarket dan 2 lokasi pasar tradisional. Hasil dari penelitian ini adalah terdapat cemaran pada 1 sampel daging ayam yang bersal dari pasar tradisional sedangkan sampel daging ayam di supermarket tidak tercemar bakteri $E$. coli dan sampel daging ayam di supermarket memenuhi persyaratan SNI untuk pemeriksaan Angka Lempeng Total bakteri E.coli. Sedangkan untuk sampel daging ayam dari pasar tradisional salah satunya tidak memenuhi syarat SNI Angka lempeng total bakteri E.coli. Setelah melakukan penelitian maka, beberapa rekomendasi saran yang dapat diajukan adalah Dapat dilakukan penelitian lanjutan untuk pemeriksaan seluruh parameter terhadap daging ayam sesuai dengan SNI agar didapatkan kesimpulan apakah daging ayam tersebut layak dikonsumsi atau tidak. Dapat dilakukan penelitian lanjutan dengan memeriksa air untuk pengolahan daging ayam.
\end{abstract}

Kata Kunci: Escherichia coli, Daging ayam, Pasar Tradisional, Identifikasi, Cemaran

*Jurusan Analis Kesehatan Poltekkes Banten 


\section{PENDAHULUAN}

Dirjen Peternakan dan Kesehatan Hewan Kementan Syukur Irwanto mengatakan, konsumsi nasional akan daging ayam tahun 2014 sebesar $8 \mathrm{~kg}$ per kapita per hari. Sementara produksi daging ayam dapat mencukupi hingga $15 \mathrm{~kg}$ per kapita per tahun. ${ }^{(2)}$

Bahan pangan asal hewan yaitu daging dan olahannya merupakan media yang sangat baik bagi pertumbuhan mikroba dan menyebabkan bahan pangan yang mudah rusak. Macam mikroba patogen yang dapat mengkontaminasi makanan diantaranya Salmonella sp., Staphylococcus aureus, Escherichia coli, Clostridium botulinum, Campylobacter sp.

Bakteri tersebut dapat menyebabkan foodborne disease. Foodborne disease adalah penyakit yang disebabkan karena mikroba dan atau toksin yang masuk ke dalam tubuh melalui makanan. ${ }^{(3)}$

Escherichia coli, atau biasa disingkat $\quad$ E. coli, adalah spesiesbakteriGram negatif, dapat ditemukan dalam usus besarmanusia dan kebanyakan tidak berbahaya bahkan yang dapat menguntungkan manusia dengan memproduksi vitamin $\mathrm{K}_{2}$, atau dengan mencegah bakteri lain di dalam usus. $E$. coli tipe O157:H7, yang dapat mengakibatkan keracunan makanan yang serius pada manusia, seperti halnya pada E.coli yang mengkontaminasi daging. ${ }^{(4)}$

Keberadaan E. coli pada daging sangat dimungkinkan karena sifat fisikokimia daging yaitu water activity (wa), pH dan zat gizi mendukung pertumbuhan mikroba tersebut, keberadaan E. coli dapat menyebabkan penyakit seperti; diare berdarah, pembengkakan dan kelainan ginjal, demam, dan kelainan syaraf, dan bahkan kematian. ${ }^{(5)}$

Kasus infeksi akibat E.coli di Amerika dalam setahun diperkirakan terdapat 158.840 kasus infeksi E.coli, dikarenakan E. coli yang dapat dijumpai pada daging masak yang terkontaminasi. ${ }^{(5)}$

$$
\text { Daging yang biasanya }
$$
terkontaminasi E. coli yaitu daging unggas. Daging unggas cocok sebagai media perkembangan mikroba, karena unggas cenderung berada di lingkungan yang kotor, cemaran daging unggas di Indonesia juga dapat disebabkan oleh rendahnya tingkat pengetahuan peternak, kebersihan kandang, serta sanitasi air dan pakan. Sanitasi kandang yang kurang baik dapat menyebabkan timbulnya cemaran bakteri patogen yang tidak diinginkan. ${ }^{(6)}$

Kerusakan karkas selama pemotongan ayam mencapai 10-20\%. Kerusakan terbesar (90\%) disebabkan karena adanya memar-memar yang terjadi 
1-13 jam sebelum pemotongan dan $38 \%$ terdapat pada bagian dada dan paha, sehingga bakteri lebih mudah mengkontaminasi daging ayam bagian dada dan paha. ${ }^{(2)}$

UPT Balai Pengembangan Peternakan dan Pelayanan Kesehatan Hewan (UPT BP3KH) Dinas Pertanian dan Peternakan Provinsi Banten, mempunyai kewenangan melaksanakan pengujian penyakit hewan dan bahan hasil

\section{Metode penelitian}

Desain Penelitian menggunakan deskriptif Laboratorik. Populasi : seluruh daging ayam yang dijual di Pasar Tradisional dan Supermarket kota Tangerang. Sampel : Sebanyak 4 potong fillet daging ayam yang dijual di Pasar Tradisional dan Supermarket kota Tangerang. Tempat penelitian dilaksanaksanakan di Laboratorium Mikrobiologi Analis Kesehatan Politeknik Kesehatan Kemenkes Banten. Pengolahan data menggunakan uji statistik Prevalensi/prosentase.

Tahapan penelitian:Menyiapkan alatalat dan pereaksi, Menyiapkan sampel daging yang akan diteliti dari 2 pedagang di pasar Tradisional dan 2 Supermarket kota Tangerang, daging ayam bagian dada dengan berat setiap sampel 100 gram, Pengamatan Daging Ayam secara Direct, Pengamatan daging ayam secara direct hewan menyatakan bahwa $70 \%$ sampel daging dari pasar tradisional di Kota/Kabupaten di Banten telah tercemar oleh mikroba, seperti E. coli, Enterococci sp, dan Staphylococcus aureus. ${ }^{(2)}$

Berdasarkan uraian tersebut, penulis mengajukan penelitian dengan judul dan Angka lempeng total bakteri Escherichia coli pada Fillet Daging Ayam Dari Pasar Tradisional Dan Supermarket wilayah Cikokol Kota Tangerang

(langsung) dilakukan dengan membuat sediaan direct. Sediaan ini dibuat dengan mengoleskan objek gelas pada permukaan daging ayam, kemudian dilihat secara mikroskopis keberadaan bakteri gram positif dan gram negatif. Pengamatan daging ayam secara langsung dilihat pula dengan organoleptik, dilihat fisik, aroma, dan warna sampel daging ayam. Identifikasi E. coli secara Mikroskopis, dilakukan dengan melakukan pewarnaan gram. Dilakukan pengujian Angka Lempeng Total untuk bakteri E. Coli. Pengumpulan data Data yang digunakan dalam penelitian adalah data primer. Data penelitian diperoleh dari hasil pemeriksaan Escherichia coli pada daging ayam yang akan diteliti dari 2 pedagang di pasar Tradisional dan 2 Supermarket kota Tangerang.

Data hasil pemeriksaan dilaporkan dalam bentuk persentase sampel yang 
tercemar Escherichia coli, analisis batas maksimum jumlah E. coli pada deskriptif jumlah E. coli pada sampel, dan sampel berdasarkan SNI 01-3924-2009. jumlah sampel yang memenuhi syarat

\section{Hasil}

Tabel 1. Pemeriksaan Mikroskopik Daging Ayam

\begin{tabular}{|c|c|}
\hline $\begin{array}{l}\text { Nomor } \\
\text { Sampel }\end{array}$ & Pemeriksaan Mikroskopik Pewarnaan Gram Perbesaran 1000x \\
\hline 1 & Ditemukan Bakteri Gram Negatif Batang \\
\hline 2 & Ditemukan Gram Negatif Batang, hifa dan spora jamur \\
\hline 3 & Ditemukan Gram Negatif Batang \\
\hline 4 & Ditemukan Gram Negatif Batang, hifa dan spora jamur \\
\hline
\end{tabular}

Tabel 2. Hasil Pemeriksaan ALT Bakteri

\begin{tabular}{|c|c|c|c|c|c|c|c|}
\hline \multirow{2}{*}{$\begin{array}{l}\text { Nomor } \\
\text { Sampel }\end{array}$} & \multicolumn{4}{|c|}{ Hasil } & \multirow[t]{2}{*}{ Hasil Akhir } & \multirow{2}{*}{$\begin{array}{c}\text { SNI 01- } \\
\text { 3294-2009 }\end{array}$} & \multirow{2}{*}{ Kesimpulan } \\
\hline & $10^{-2}$ & $10^{-3}$ & $10^{-4}$ & $10^{-5}$ & & & \\
\hline 1 & 0 & 0 & 0 & 0 & Negatif & \multirow{4}{*}{ 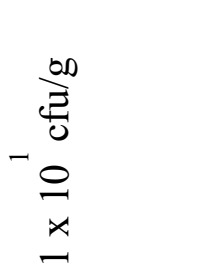 } & Memenuhi syarat \\
\hline 2 & 0 & 0 & 0 & 0 & Negatif & & Memenuhi syarat \\
\hline 3 & 0 & 0 & 0 & 0 & Negatif & & Memenuhi syarat \\
\hline 4 & 282 & 132 & 36 & 8 & $\begin{array}{l}1,7 \times 10^{5} \times 1 \\
\mathrm{cfu} / \mathrm{g}\end{array}$ & & $\begin{array}{ll}\text { Tidak } & \text { Memenuhi } \\
\text { syarat } & \end{array}$ \\
\hline
\end{tabular}

Didapatkan hasil akhir untuk sampel dari supermarket yaitu sampel 1 dan 2 negatif atau memenuhi syarat untuk pemeriksaan Angka Lempeng Total E. coli. Sedangkan untuk sampel pasar tradisional didapatkan hasil sampel 3 negatif memenuhi syarat untuk pemeriksaan Angka Lempeng Total $E$. coli. Untuk sampel 4 tidak memenuhi syarat karena Angka Lempeng Total Bakteri E.coli $1,7 \times 10^{5} \mathrm{cfu} / \mathrm{g}>1 \times 10^{1} \mathrm{cfu} / \mathrm{g}$ (SNI 01-3294-2009).

Escherichia coli merupakan bakteri yang masuk dalam famili Enterobacteriaceae yang merupakan penghuni normal saluran pencernaan hewan berdarah panas seperti halnya manusia dan ternak sehingga terdapat pada 
feses. Adanya bakteri tersebut dapat dijadikan sebagai indikator bahwa daging ayam tersebut telah tercemar oleh feses baik manusia maupun hewan. Selain itu, bakteri indikator ini juga menandakan bahwa adanya proses penanganan yang kurang higienis.

\section{Simpulan}

Terdapat cemaran pada 1 sampel daging ayam yang bersal dari pasar tradisional sedangkan sampel daging ayam di supermarket tidak tercemar bakteri $E$. coli. Sampel daging ayam di supermarket memenuhi persyaratan SNI untuk pemeriksaan Angka Lempeng Total

\section{Daftar pustaka}

1. Direktorat Jenderal Pemberantasan Penyakit Menular Badan Penelitian Dan Pengembangan Kesehatan. 2004. Kajian Riset Operasional Intensifikasi Pemberantasan Penyakit Menular Tahun 1998/1999 - 2003. Jakarta.

2. Survei Sosial Ekonomi Nasional, 2010 -2014 .

3. Bonang, Gerard \& Enggar S. Koeswardono. 1982. Mikrobiologi Kedokteran untuk Laboratorium dan Klinik. Jakarta: PT. Gramedia.

4. Lay, Bibiana. 1994. Analisis Mikroba di Laboratorium. Jakarta: PT. Raja Grafindo Persada.
5. Staf Pengajar FKUI. 1994. Mikrobiologi Kedokteran. Jakarta: Binarupa Aksara.

6. Moeliono AM. 1990. Kamus Besar Bahasa Indonesia. Balai Pustaka Jakarta.

7. Murray, Patrick R,. 2002. Manual of Clinical Microbiology (9th edition) Washington D.C: ASM PRESS.

8. SNI No. 01-6366-2000

9. Fardiaz, S. 1993. Analisis Mikrobiologi Pangan. PT. Raja Grafindo Persada, Jakarta.

10. BPOM. 2008. Pengujian Mikrobiologi Pangan. http://www.pilciran-rakyat.com. Diakses tanggal 17 Oktober 2015.

11. BPOM RI. 2006. Metode Analisis Mikrobiologi Suplemen 2000. Pusat Pengujian

Obat Dan Makanan Badan Pengawasan Obat Dan Makanan Republik Indonesia, Jakarta.

12. Buckle, K.A., R.A. Edwards, G.H. Fleet dan M. Wooton. 1987. Ilmu Pangan (Terjemahan dari Bahasa Inggris oleh H. Purnomo dan Adiono). Penerbit Universitas Indonesia, Jakarta.

13. Anonim. 2008. Eschericia coli. http://id.wikipedia.org/wiki/Eschericia coli. Diakses tanggal 17 Juni 2011.

14. Hariyadi RD. 2005. Bakteri Indikator Sanitasi dan Keamanan Air Minum. http://web.ipb.ac.id/ tpg/de/pubde_fds 
f_bctrindktr.php. Diakses tanggal 23

Oktober.

15. Brooks G.F, J.S. Butel, S.A. Morse. 2005. Medical Microbiology.

McGraw-Hills Companies Inc.

16. Firmansyah, B. 2010. Media Selektif dan Media Diferensial. http://cacingbusuk.blogspot.com/2010/ 05/media-selektif-dan-media

differensial.html . Diakses tanggal 23

Oktober 2015.

17. Cappuccino, J.G., dan N. Sherman. 2008. Mikrobiology : A Laboratory Manual: The Benjamin/Cummings Publishing Company, Inc. California. 